\title{
自己校正法による光度の測定
}

\author{
准員 吉田 正範* 専門会員 西山 英夫** 専門会員 吉 江 清***
}

\section{Measurement of Luminous Intensity by the Self-calibration Technique}

\author{
Masanori Yoshida (Semi-Member) \\ (Graduate School of Electrical Engineering, Chiba University) \\ Hideo Nishiyama (Fellow Member) \\ (Matsushita Electric Industrial Co., Ltd.) \\ Kiyoshi Yoshie (Fellow Member) \\ (Faculty of Engineering, Chiba University)
}

\begin{abstract}
This paper is concerned with a new method for measuring luminous intensity of a tungsten incandescent lamp. Absolute spectral sensitivity of a silicon photodiode was determined by the self-calibration technique developed by the NBS, and a $\mathrm{V}(\lambda)$ Correction filter and a diaphragm of known opening area combined with this photodiode were used for the photometer.

Uncertainty of the measurement was estimated to be about $1 \%$, and this method was considered to be a satisfactory practical method for the luminous intensity measurement without using a photometric standard source.
\end{abstract}

\section{1.はじめに}

1980年にアメリカのN B S (National Bureau of Standards) が発表したシリコンホトダイオードの自己校正法は, シリコンホ トダイオードの絶対分光応答度を測定する方法である $\left.{ }^{1)}, 2\right)$. この 方法の特長は，高度な設備がととのっていない研究室でも比較的 簡単な測定技術で，シリコンホトダイオードの絶対分光心答度を 測定でをるととにある，千葉大学および松下電器産業(侏照明研究 所でもこの方法に着目し，数年前より研究を続けてきだ)。 その 結果, 千葉大学における測定值と, 電子技術総合研究所における 測定值は，0.5\%以内の精度で一致していることがわかり，自己 校正法が有効な手段であることが確かめられている4．

本研究では，上で述べた自己校正法によって, 絶対分光応答度 を測定したシリコンホトダイオードを用いて，任意の電球の光度 を測定する方法を考案し，乙れを光度標潐電球の道校正法と名づ けた。 また，この方法により，A社で光度を測定済みの白熱タン グステン標準電球の光度を逆校正し，その測定值との比較検討を 行なった.

* 千堡大学大学院工学研究科暼気工学専攻 Graduate School of Electrical Engineering, Chiba University

** 松下電器産業株式会社照明研究所 Lighting Research Laboratory, Matsushita Electric Ind. Co., Ltd.

*** 千集大学工学部 Faculty of Engineering, Chiba University
さらに，光度標準電球の逆校正法により，光度の值を决定した 電球を用いて，試作した照度計の照度の目盛りを校正し，この照 度計とB社の照度計の照度目盛との比較を行ない，これについて も検討した。

\section{2. 光度標準電球の逆校正法}

\section{1 逆校正法の原理}

図 1 亿光度標準電球の逆校正法の原理図を示す。構造図にあ るシリコンホトダイオードは, 自己校正法により可視域にわたる 絶対分光応答度 $R(\lambda)$ を 400〜 500 および $600 \sim 700[\mathrm{~nm}]$ の範 井で $20[\mathrm{~nm}] お を に$ また，500〜600[nm]の範井では 10 〔nm]おをに測定したものである。をた，視感度補正フィルタ は，その分光透過率 $\tau(\lambda)$ の相対值が， $V(\lambda) / R(\lambda)$ 飞近似する よ5に（ただし， $V(\lambda)$ は標準比視感度）松下電器産業(侏照明研 究所において設計，製作したもので，色ガラスフィルタを 3 枚重 ねて密着させた構造をしており，大きさは $50[\mathrm{~mm}] \times 50$ $[\mathrm{mm}] \times 7[\mathrm{~mm}]$ である. 図 2 亿示すよ5な測定システムにより 千葉大学においててのフィルタの分光透過率を, 可視域の範囲で $10[\mathrm{~nm}]$ おきに測定した結果の概要を図 3 亿示す．このとき， シリコンホトダイオードの表面にはフィラメントの像ではなく， レンズ 2 Kよって適当な穴あき板の穴の像を結ばせ，入射光が一 様となるよらに配虑した。なお，本測定の再現性は，標準偏差が 最大0.0008であった。

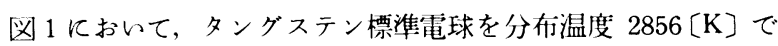
点灯し, シリコンホトダイオードの出力電流 $i[\mathrm{~A}]$ を測定する. 


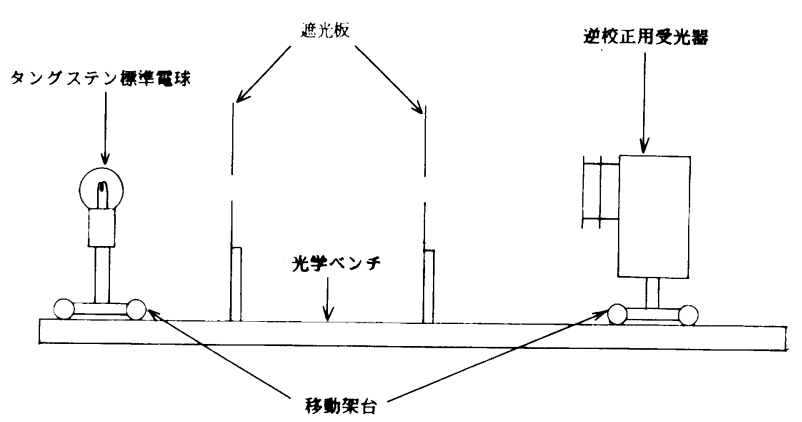

因 1 (a) 光度標准電球の逆校正の光学系

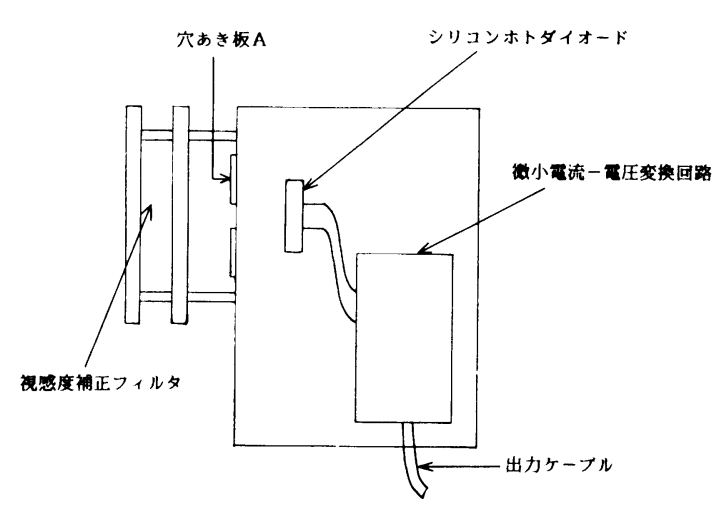

图 1 (b) 逆校正用受光器の構造図

このとをの出力電流 $i$ は, 以下の式で与えられる.

$$
i=C \int_{0}^{\infty} \tau(\lambda) R(\lambda) S_{\lambda}(\lambda) d \lambda
$$

ここで, $\mathrm{S}_{\lambda}(\lambda)$ は分布温度 $2856[\mathrm{~K}]$ のタングステン電球から 発して, 穴の面積既知の穴あき板 $A$ を通過した放射束の分光分布 の相対值で, $S_{\lambda}(\lambda)$ はプランクの放射則からえられる完全放射体 の分光分布と相対的によく近似しているとみるてとができる. $C$ は比例定数である.

一方，この穴あき板 $A$ を通過した光束 $\phi_{U}$ は，次式で表わす ととができる.

$$
\Phi_{v}=C \cdot K_{m} \cdot \int_{0}^{\infty} V(\lambda) S_{\lambda}(\lambda) d \lambda
$$

$K m:$ 最大視感度 $=683[\mathrm{~lm} / \mathrm{W}]$

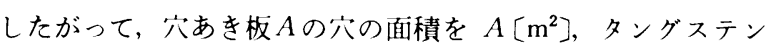
電球から穴あを板 $A$ までの距離を $s[\mathrm{~m}]$ とすると, タングステ ン電球の光度 $I_{v}$ は

$$
I_{v}=C \cdot K_{m} \cdot s^{2} \int_{0}^{\infty} V(\lambda) S_{\lambda}(\lambda) d \lambda / A
$$

と表わされ，さらにてれと式(1)より

$$
I_{v}=K_{m} \cdot \frac{s^{2}}{A} \cdot \frac{\int_{0}^{\infty} V(\lambda) S_{\lambda}(\lambda) d \lambda}{\int_{0}^{\infty} \tau(\lambda) R(\lambda) S_{\lambda}(\lambda) d \lambda} \cdot i \ldots \ldots \ldots \ldots \ldots(4)
$$

として光度Ivを求めることができる.

以上により, 眓1のような実験システムでシリコンホトダイオ 一ドの出力電流 $i$, タングステン電球から穴あき板 $A$ はでの距離 $s$ を測定すれば, 式(4)からタングステン電球の光度が測定でき, 光度標準電球の逆校正が実現できる. ここでフィルタとホトダィ オードを組み合わせたものの絶対応答度を, 正規化した相対分光 応答度 $S(\lambda)$ と係数 $a[A / W]$ を用いて $\tau(\lambda) R(\lambda)=a \cdot S(\lambda)$ と すると, 式(4)はさらに

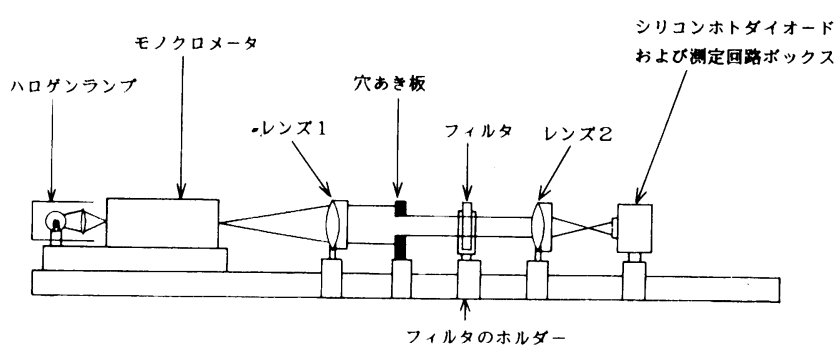

因 2 視感度補正フィル夕の分光透過率測定の光学系

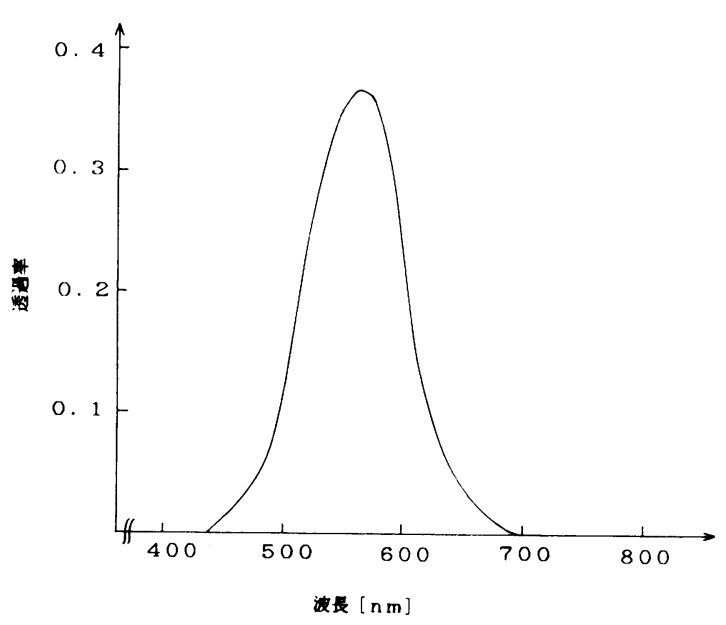

因 3 視感度補正フィルタの分光透過率の測定結果

$$
I_{v}=K_{m} \frac{s^{2}}{A} \cdot \frac{1}{a} \cdot \frac{\int_{0}^{\infty} V(\lambda) S_{\lambda}(\lambda) d \lambda}{\int_{0}^{\infty} S(\lambda) S_{\lambda}(\lambda) d \lambda} \cdot i
$$

で表わされる. 式(5)中の $\int_{0}^{\infty} V(\lambda) S_{\lambda}(\lambda) d \lambda / \int_{0}^{\infty} S(\lambda) S_{\lambda}(\lambda) d \lambda$ は $V(\lambda)$ と $S(\lambda)$ が完全に一致しない場合の補正項であり, 計算によって 求めることができる. ここで $a[A / W] は S(\lambda)$ がピークの時の 絶対分光応答度を意味する.

穴あき板 $A$ はステンレス鋼（熱膨張率（線膨張率） $\alpha=1.64$ $\left.\times 10^{-5}\right)$ で作られた精密アパーチャである．穴の形は平均直径

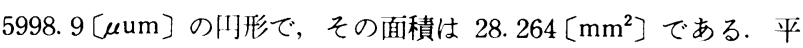
妁直径（真円度測定機と精密測長機による）の測定精度は土1 〔um]以内であるので，穴の面積精度は土0.03\%である.

\section{2 逆校正法による光度測定}

使用した 3 個のタングステン電球は, ランプ番号 SB 20717, HA 20010C とNo.3で分布温度 2856 [K]で点灯したときの光度 が，それぞれ $262[\mathrm{~cd}], 364[\mathrm{~cd}], 320[\mathrm{~cd}]$ と与えられている. この值は，A社において直流電源を使用して測定した值である.

本研究では, 図1で示した実験システムにより, 電球と穴あき 板 $A$ の距離 $s=1.5[\mathrm{~m}]$ で測定を行なった. 電球のガラス球の 最大寸法は， 3 個とも $s$ の $1 / 10$ 以下であるので，乙の距離で測定 すれば，われわれの測光精度内で電球は点光源々みなすととがで きる. 電球と逆校正用受光器は, 測光べンチ上に装置したそれぞ れ専用の移動架台に取り付け, 電球のフィラメントと受光器のフ イルタおよび穴あき板Aが正対するよらに配置した．なお受光器 の穴あき板 $A$ より電球側にフィルタがあるために生じる光路差と して, 2. 3[mm]の距離の補正を行なった. 表 1 飞 3 個の光度 標準電球の逆校正法による，光度の測定結果を示すＡ社と千葉 大のひらきとは, $\mathrm{A}$ 社の測定值に対する千葉大の逆校正值のひら 
表 1 米度標㷪簐球の道校正の実呀結果

\begin{tabular}{|c|c|c|c|c|}
\hline ランプ番号 & $\begin{array}{c}\text { 光度 (cd) } \\
\text { (A kt. })\end{array}$ & $\begin{array}{c}\text { 逆校正値 }(\mathbf{c d}) \\
(\text { 下集大 })\end{array}$ & $\begin{array}{l}\text { 逆校正值の } \\
\text { 再現性 }(\%)\end{array}$ & $\begin{array}{l}\text { A社と千葉大 } \\
\text { のUらう }(\%)\end{array}$ \\
\hline SB20717 & 262 & 265 & 0.09 & +1.1 \\
\hline HA20010C & 364 & 366 & 0.55 & +0.5 \\
\hline No. 3 & 320 & 324 & 0.53 & +1.3 \\
\hline
\end{tabular}

きの百分率である．A社とおける光度の測定値を正しいものと し, 千葉大の逆校正值の評価を行な 5 , 誤差は $1.3 \%$ 以内, 測 定の再現性は $0.55 \%$ 以内であった. 現在, 各国の国立研究所が光 度を測定した標準電球を国際度量衡局に持ちより，互いに比較し た場合でも，その結果には約 $2 \%$ の゙らつきが見られることよ り, 上で述べた逆校正法による測定結果は, 満足できるものであ ると思われる。

\section{3. 自己校正型照度計の試作}

\section{1 照度計の原理}

前節で述べた方法によって電球の光度を校正し，任意の安定な タングステン電球を光度標準電球に仕立てることができた。 そこ で, その電球を基準として, 試作した照度計の照度の目盛りづけ を行なった。このよらにして校正した照度計は, 測光量の標潐器 を使用せずに照度の目盛りづけがでをるので，自己校正型照度計 と名付けた. 図 4 K, この照度計の構造図を示す. 図中の球殼 状拡散透過板は，可視域における波長選抧性がきわめて少ないも ので，人射光がどの角度から入射しても，照度計の出力が入射の 余弦則に従らようにするためのものである. シリコンホトダイオ 一ドと視感度補正フィルタは, 前節で述べたものと同じものを使 用している. したがって, とのフィルタとシリコンホトダイオー ドを組み合わせたときの相対分光応答度は，標準比視感度に近似 している. シリコンホトダイオードの出力は，OPアンプICを用

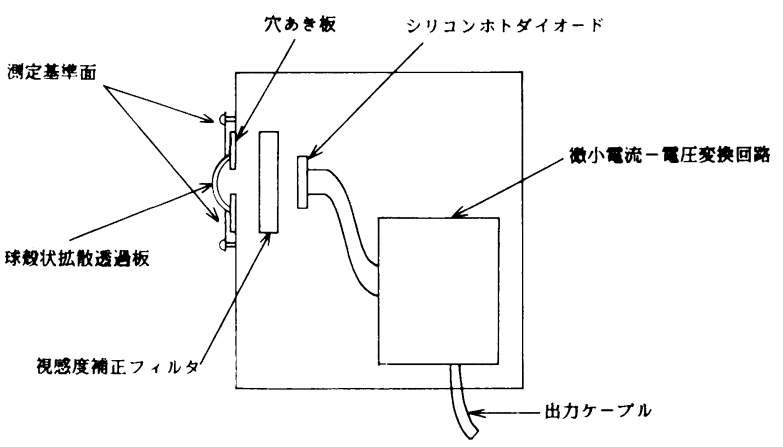

图 4 自己校正型照度計の構造

いて構成した微小電流一電压変換回路により電压として取り出 す. したがって，照度計としての出力は電圧值である。このため 照度の目盛りづけは, 測定基準面の単位照度あたりの出力電圧值 を照度応答度 $R_{E}[\mathrm{~V} / \mathrm{l} \mathrm{x}]$ として測定した。

図 5 亿照度計の照度応答度 $R_{E}$ の測定システムを示す. この 測定には，ランプ番号No.3の電球を用いた。電球と照度計は, 測光ベンチ上でそれぞれ専用の移動架台に取り付け, 電球の光度 既知の方向が照度計の測定基準面の中心を垂直に通るよらに配置 した。 また，電球と照度計の間に遮光板を二つ置き，電球よりの 直接光以外の光が，照度計に入射しないようにした。

測定の結果，本研究で試作した照度計の照度応答度 $R_{E}$ は,

$R_{E}=0.201 \pm 0.001[\mathrm{mV} / \mathrm{lx}]$

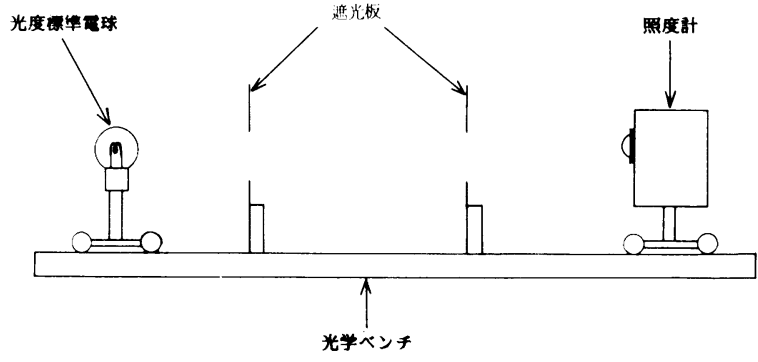

图 5 照度計の校证の光学菜

であった。

\section{2 照度計の精度}

試作した自己校正型照度計と B 社の D 900 型照度計（計量法 による検定済）による照度測定值についての相互比較を行なっ た. 以下これについて述べる.

実験は前節の図 5 と同様のシステムで，二つの照度計を交互に 置き換えて行なった。 その際，照度計以外の光学系は動かさない よらに注意を払った. 実験に使用した電球は,ランプ番号 SB 2071 7 と HA 20010 C の 2 個である．表 2 亿実験結果を示す.

表 2 の 2 つ照度計のひらをとは，D 900 型照度計による測定 值に対する自己校正型照度計による測定值のひらきの百分率であ る.乙れをみると，二つの照度計の指示值は，3.5\%以内で一致 しており，特飞 $200[\mathrm{~lx}]$ 以下の照度では，1.5\%以内と良い一 致がみられた：二つの照度計が独立した全く異なる方法で校正さ れたととを考えるとほば満足できる結果であると思われる。

表 2 自己校正型照度計（千葉大）とD900型照度計（B社）との此較

\begin{tabular}{|c|c|c|c|c|}
\hline ランブ番号 & $\begin{array}{l}\text { 電球と測定基淮 } \\
\text { 面の距離 }(\mathrm{m})\end{array}$ & $\begin{array}{l}\text { 自己校正型照度 } \\
\text { 計指小値 }(\mathbf{l} \mathbf{x})\end{array}$ & $\begin{array}{l}\text { D } 900 \text { 型照度 } \\
\text { 部指示值 }(\mathbf{l} \mathbf{x})\end{array}$ & $\begin{array}{l}2 つ の \text { 照度叶 } \\
\text { のひらき }(\%)\end{array}$ \\
\hline \multirow{3}{*}{ SB20717 } & 1.5 & 120 & 119 & +0.84 \\
\hline & 1.25 & 171 & 170 & +0.59 \\
\hline & 1.00 & 267 & 261 & +2.30 \\
\hline \multirow{3}{*}{$\mathrm{HA} 20010 \mathrm{C}$} & 1.5 & 163 & 161 & +1.24 \\
\hline & 1.25 & 233 & 227 & +2.64 \\
\hline & 1.00 & 363 & 351 & +3.42 \\
\hline
\end{tabular}

\section{4.むす び}

本研究では，自己校正法により絶対分光応答度を測定したシリ コンホトダイオードを用いて，任意の電球の光度を測定する方法 を考案し，その精度も満足すべきものが得られた．なお，本研究 で用いた視感度補正フィルタの場合, 分布温度 $2856[\mathrm{~K}]$ 付近の 電球の分布温度が $30[\mathrm{~K}]$ 以内の正確さで知れていれば，式(5)の 補正項の 1 からのハズレは $1 / 1000$ 以下となるととが計算で確かめ られている，一方，自己校正法によるオキサイドバイアス特性測 定後の応答度低下の現象が報告5)されており, 今後の課題として 研究を続ける必要がある。

試作した白己校正型照度計は，200〔lx〕以下の照度の測定に おいては，満足できる結果がえられたが，200[lx]以上の照度 の測定では，市販の照度計による測定とのズレが大きかった．と れについては，今後，さらに実験をかさねてその原因を追及する 予定である。また，ての自己校正型照度計が一般に使用されるに は，JIS 1609 で規定された条件（分光応答度特性，入射角特性 など）を満足しなければならないので，てれもあわせて検討する 
予定である.

今後, この測定法の精度を高めることにより, 測光量の標準器 を持たない研究室でも, 自己校正法による絶対分光忍答度を測定 したシリコンホトダイオードを用いて, 光度標準電球や照度計さ らには輝度計を校正できる可能性が十分にあると考えられる。

最後に, この研究にあたって種々ので指導, で助言をいただい た下葉大学工学部, 田中国昭教授, 大川澄雄教授, 吉川明彦助教 授, 島倉信講師, 吉田利信助手, 佐藤直樹大学院生に厚く感謝を 申し上げるとともに，ご協力をいただいた（株）東芝照明開発研 究部長広瀬吉夫氏ならびに照明事業部照明品質保証部課長石野正 敏氏に御礼を申し上げます。

参 考 献

(1) Zalewski, E.F. and Geist, J. : Silicon photodiode absolute spectral response self-calibration, Appl. Opt. 19-8 (1980) 1214 1216

(2) Geist, J. E. F. Zalewski, and Schaefar, A. R. : Spectral response self-calibration and interpolation of Silicon photodiode, Appl. Opt. 19-22(1980) 3795〜3799

(3) 鶴岡浩文, 吉江 清: シリコンホトダイオードの分光忍答 度の推定, 照学誌 69-10（昭61） 531〜536

(4) 吉田, 吉江, 斉藤, 三嶋 : シリコンホトダイオード自己校 正法の精度, 昭和61年度（第19回）照明学会全国大会予 稿, P. 45

（5）大野義弘，西山英夫：シリコンホトダイオードの自己校正 法におけるオキサイドバイアス特性の検討, 昭和 62 年度 （第20回）照明学会全国大会予稿 P. 45

（受付1987年 4 月28日）

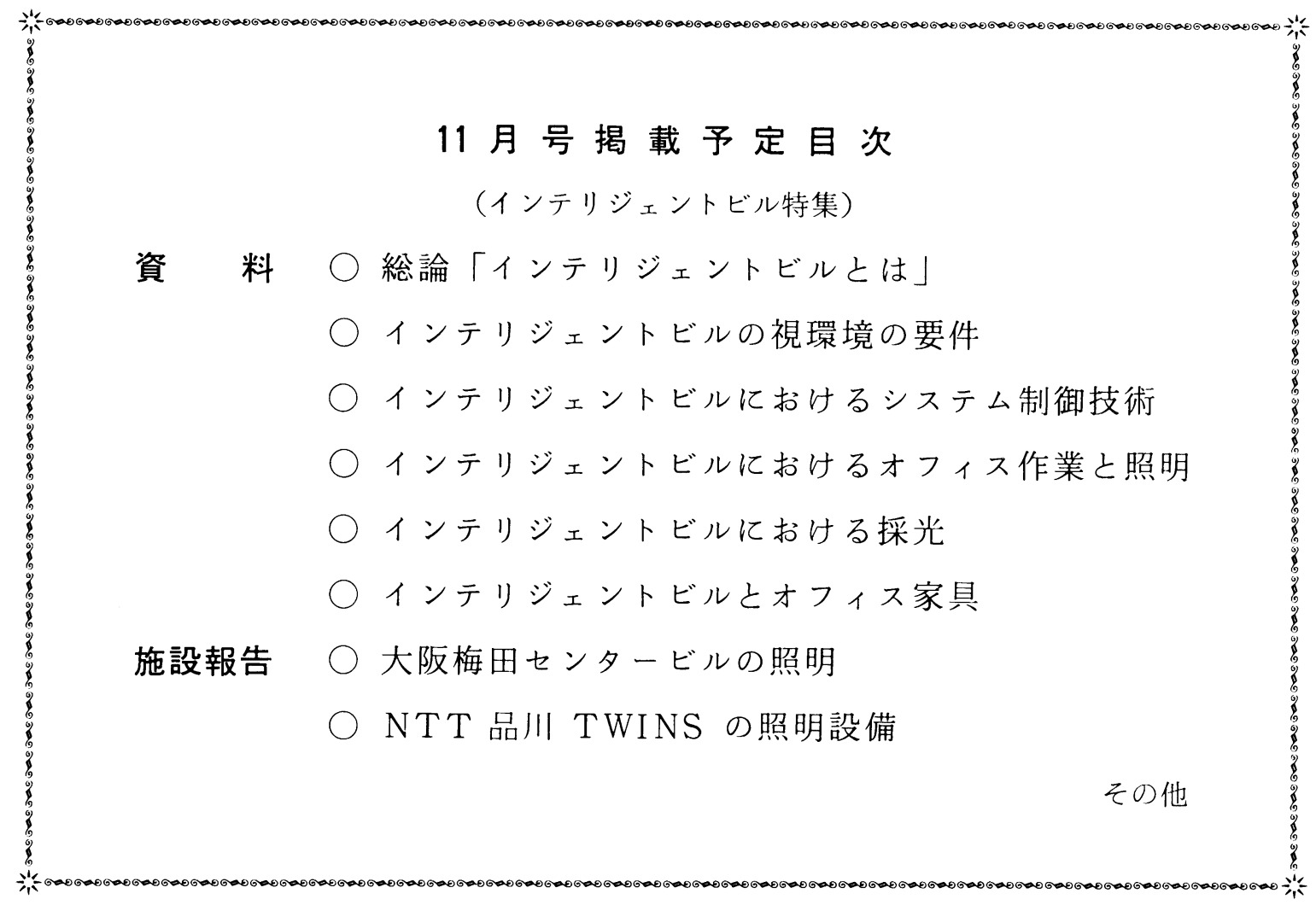

